\title{
Iwona Loewe, Gatunki paratekstowe w komunikacji medialnej, Wydawnictwo Uniwersytetu Śląskiego, Katowice 2007, ss. 244
}

Książka Iwony Loewe sytuuje się w obszarze genologii lingwistycznej, teorii komunikacji (komunikologii) i medioznawstwa. Przedmiotem badań autorki są parateksty rozpatrywane w czterech kontekstach: teoretycznoliterackim, językoznawczym, edytorskim i komunikologicznym. Śląska lingwistka posługiwała się zrazu w swych badaniach i publikacjach terminem pre-tekst, zasadnie przysługującym „tekstowym strategiom uprzedzania odbioru tekstu właściwego" (s. 11), zarzuciła go jednak ze względu na ustabilizowane już literaturoznawcze znaczenie terminu, a także ze względu na potoczny (obiegowy) sens wyrazu pretekst. W rozprawie przyjęła termin paratekst, rozumiany jako „taki tekst, który eskortuje tekst właściwy [...], często wielokodowy, w którym jednak udział (mniej lub bardziej znaczący) ma kod werbalny. Paratekst ma za zadanie uczynić z korpusu tekst łatwo dostępny w projektowanym dla niego środowisku odbiorczym, a środowisko to uczynić jak najliczniejsze. W tym celu ma zaprezentować tekst właściwy (w tożsamym środowisku nadawczym) i zachęcić do jego odbioru, pozostawiając możliwość interpretacji samemu odbiorcy” (s. 23). Funkcję tak rozumianego paratekstu określa autorka jako „prezentacyjno-rekomendującą z różnym nasileniem obu członów w konkretnych realizacjach" (s. 23).

Z paratekstów badaczka wyłącza okazy w całości autorskie, słusznie uznając je za metatekst: „Autorem paratekstu w ujęciu globalnym nie jest autor tekstu właściwego (to relacja metatekstowa), ale osoba trzecia (dystrybutor filmu kinowego, prezenter programu radiowego lub telewizyjnego, wydawca książki, redaktor wydania czasopisma, administrator portalu internetowego itd.” (s. 24). Zasadnie (co trzeba podkreślić, gdyż jest to istotne novum na tle dotychczasowej literatury przedmiotu) autorka twierdzi, że nadawca 
(choć istotny przy rozróżnieniu paratekstu i metatekstu) nie jest dla paratekstu kategorią najistotniejszą - ważniejszy jest tu odbiorca: „Odbiorca jest dla paratekstów ważniejszą kategorią niż nadawca, ponieważ nie tylko korpus, ale i paratekst poszukują swej publiczności i jest to ta sama publiczność. To znaczy, że od mocy rekomendującej paratekstu zależy także liczba odbiorców dzieła" (s. 24).

Wreszcie ostatnie ograniczenia zakresu pojęcia paratekstu wynikają z przyjętego przez autorkę pojęcia tekstu (autorstwa Jerzego Bartmińskiego jak sama pisze, dość tradycyjnego, a przynajmniej nie postmodernistycznego) jako ,ponadzdaniowej jednostki językowej, makroznaku, mającego określone nacechowanie gatunkowe i stylowe, poddającego się całościowej interpretacji semantycznej i komunikatywnej, wykazującego integralność strukturalną oraz spójność semantyczną i podlegającego wewnętrznemu podziałowi semantycznemu, logicznemu i kompozycyjnemu" (s. 27). Warunek tak rozumianej tekstowości autorka nakłada i na paratekst.

W teoretyczno-metodologicznej części rozprawy na szczególne podkreślenie zasługują jeszcze trafne i przekonujące uzasadnienie synkretyzmu metodologicznego (tu określonego mianem polimetodologii): „Było dla mnie oczywiste na pewnym etapie oglądu gromadzonego materiału, że uprawnionym paradygmatem badawczym będzie polimetodologiczne wspólczesne językoznawstwo. Radzi sobie ono bowiem dziś już z opisem nie tylko systemu (dzięki strukturalizmowi), ale także z opisem użycia tegoż w komunikacji (dzięki gramatyce komunikacyjnej i pragmalingwistyce), z opisem odbicia kultury w komunikacji językowej (dzięki etnolingwistyce, lingwistyce kulturowej), z opisem ścieżki myślenia wyrażonej w języku (dzięki kognitywistyce), z opisem poprawności i dysfunkcji językowej (dzięki lapsologii, językoznawstwu stosowanemu i neurojęzykoznawstwu)" (s. 30) oraz wnikliwe rozpatrzenie relacji między komunikologią a medioznawstwem.

Centralne dla rozprawy (przypomnijmy jej tytuł: Gatunki paratekstowe $w$ komunikacji medialnej) pojęcie gatunku rozpatruje autorka w kontekstach metodologicznych literaturoznawstwa, filmoznawstwa, medioznawstwa i wreszcie językoznawstwa. Słusznie przypomina, że choć genologia lingwistyczna sięga początkami zaledwie lat siedemdziesiątych ubiegłego wieku, to jej przedmiot („Genologia lingwistyczna zajmuje się [...] językowymi sposobami ludzkiego komunikowania się, które są w czasie i miejscu przez daną społeczność ze swoją kulturą i tradycją używane, powtarzane, w ten sposób utrwalane i rozpoznawane przez następne pokolenia”, s. 55), czyli gatunki (genry) mowy, istnieje, odkąd istnieje język ludzki.

Stając na gruncie genologii lingwistycznej, uwzględniając jednak konieczny tu aspekt medioznawczy (,Jeśli intencja jednoczy wszystkie zebrane 
przeze mnie parateksty, to medium je rozróżnia" (s. 64), pozwalając na wyróżnienie paratekstów książkowych, prasowych, radiowych, telewizyjnych, kinowych czy internetowych), autorka przyjęła następującą definicję gatunku: „za gatunek uznaję względnie trwały pod względem tematycznym, kompozycyjnym i stylistycznym sfunkcjonalizowany typ wypowiedzi, ukształtowany przy udziale kulturowej wiedzy jego nadawcy przez właściwe w danym czasie, miejscu i kulturze okoliczności obcowania językowego, wyrażony za pośrednictwem danego medium, przez odbiorcę postrzegany zaś jako koherentna i skończona całość komunikacyjna" (s. 64). Definicję tę należy uznać za trafną i wyczerpującą. Na jej podstawie autorka wyodrębniła następujące gatunki paratekstowe: „książkowa nota wydawcy, prasowy lid, prasowa zapowiedź, spis treści, radiowa i telewizyjna zapowiedź (zajawka), kinowy zwiastun, internetowa strona główna witryny, które choć wyartykułowane w różnych mediach, to zjednoczone z woli nadawcy prezentacyjno-rekomendującą funkcja, postrzegane w bliskości czasowej lub przestrzennej tekstu bazy przez współczesnego odbiorce jako koherentne i skończone całości, wyrażające makrostrukturę korpusu, konieczne we współczesnej kulturze nadmiaru i dyspersji, kierujące uwagę odbiorcy w stronę tekstu głównego" (s. 65).

Teoretyczno-metodologiczną część rozprawy zamyka bardzo gruntowne i precyzyjne odróżnienie paratekstu od metatekstu (znakomita, wyczerpująca charakterystyka paratekstu w opozycji do metatekstu na s. 78) i paratekstu od reklamy (tu I. Loewe trafnie i wnikliwie rozstrzyga, co jest, a co nie jest reklamą - na przykład nie są nią teksty public relations, promocja sprzedaży, personal selling, sponsoring, publicystyczny tekst sponsorowany, teksty na opakowaniach produktu i wreszcie parateksty; za przypadki graniczne uznaje autorka przejawy autopromocji).

Rozwiodłem się trochę szerzej nad teoretyczno-metodologicznymi podstawami rozprawy, gdyż jej wartość polega - w moim przekonaniu - na tym, że:

1. Stanowi ona - jako zwornik najważniejszych nurtów dotychczasowej twórczości naukowej autorki (zbiegają się w niej wątki genologiczne, stylistyczne, pragmalingwistyczne, tekstologiczne, komunikologiczne i medioznawcze) - swego rodzaju summę poglądów I. Loewe w kwestiach teoretycznych i metodologicznych różnych paradygmatów badawczych z jednej, a działów językoznawstwa i nauk blisko z nim związanych z drugiej strony. Wiele kwestii (jak status reklamy i jej cechy konstytutywne, relacja paratekst metatekst itd.) już wcześniej rozpatrywanych, definiowanych i charakteryzowanych przez autorkę znalazło tu nowe, zwykle pogłębione, gruntowniej i wszechstronniej uzasadnione ujęcie. Obszerna (licząca 84 strony) teoretyczno-metodologiczna część rozprawy I. Loewe stanowi niezaprzeczalne świa- 
dectwo rzadko spotykanego stopnia świadomości teoretyczno-metodologicznej młodej śląskiej badaczki.

2. Zawiera - jako wynik wnikliwej i wszechstronnej analizy, przeprowadzonej na obszernym i różnorodnym materiale (na przykład w wypadku noty wydawcy uwzględniła autorka beletrystykę, literaturę dziecięcą i młodzieżowă, pamiętniki, autobiografie, biografie, podręczniki, słowniki, monografie naukowe, książki popularyzatorskie, zbiory reportaży, felietonów, poradniki, przewodniki, albumy itd.) z przełomu XIX i XX wieku (jedynie w wypadku lidu i spisu treści w prasie sięga autorka, dla celów porównawczych, w przeszłość aż do XIX wieku) - wyczerpującą charakterystykę genologiczną (obejmującą oprócz wzorca kanonicznego i jego wariantów (wzorce alternacyjne) także wzorce adaptacyjne) wszystkich uwzględnionych w rozprawie paratekstów. Taka charakterystyka to wielkiej wagi osiagnięcie naukowe.

Rozprawę Iwony Loewe trzeba polecić przede wszystkim językoznawcom i medioznawcom, ale z pożytkiem przeczytają ją także kulturoznawcy i socjologowie. 